\title{
DOES CUSTOM HAVE A SOURCE?
}

\section{Daniel Bodansky*}

Customary international law often seems like a riddle wrapped in a mystery inside an enigma. According to Manley O. Hudson, even the drafters of the International Court of Justice Statute "had no very clear idea as to what constituted international custom." The situation has not changed much since then.

I got my first taste of the difficulties in identifying custom when I was a junior attorney at the U.S. Department of State and was assigned the task of preparing the U.S. submission in a juvenile death penalty case before the Inter-American Commission on Human Rights. The juvenile death penalty is prohibited by the International Covenant on Civil and Political Rights (ICCPR) and the American Convention on Human Rights, but the question in the Inter-American Commission case was whether it is also prohibited as a matter of customary international law.

Ascertaining custom is, in theory, an empirical task, requiring one to canvas state practice and evidence of opinio juris, in order to determine whether there is a general practice accepted as law. So I set out to gather the available evidence. Fortunately for me, the State Department has vast resources at its disposal to try to ascertain state practice, so I was in an enviable position. I sent a cable to all of our diplomatic and consular posts, asking for a report on state practice in each post's host country. I requested a report from the comparative law division of the Congressional Research Service about the countries that prohibit the juvenile death penalty in their national law. I reviewed the travaux preparatoire of the ICCPR to see if there was any evidence that states thought they were codifying a pre-existing customary norm.

My conclusion after weeks of work: who knows?! The responses from posts were of highly variable quality, since answering the question required detailed knowledge of the host country's legal system, which most diplomats lack. The Congressional Research Service produced reams of information about local laws, but very little of it spoke to the issue of the juvenile death penalty, much less whether countries believe they are prohibited as a matter of customary international law from executing people for crimes committed under the age of 18. On reflection, these results were not surprising. I doubt many states have ever considered the question of the juvenile death penalty's status as a matter of customary international law, so it is unremarkable that there is little evidence of state practice or opinio juris.

If we take seriously the "official story" of identifying customary international law, summarized extremely well in Sir Michael Wood's report, then I think most efforts to identify customary international law will end, like mine, in failure. The evidentiary demands are just too high to be satisfied in the real world. Inducing the rules of customary international law from state practice would be a Herculean task-a task, by the way, more appropriate for an empirically oriented social scientist than for a lawyer.

* Foundation Professor of Law at the Sandra Day O'Connor College of Law, Arizona State University.

Note: The second half of this comment is adapted from Daniel Bodansky, Prologue to a Theory of Non-Treaty Norms, in LOOKING TO THE Future: Essays on International LaW in Honor OF W. Michael Reisman (Mahnoush Arsanjani et al. eds., 2010).

Originally published online 23 Dec. 2014.

ASIL and Daniel Bodansky (C) 2014 
But, of course, these difficulties don't stop courts, states, and publicists from finding customary international law wherever they turn. In the field of international environmental law, for example, there are putative customary norms to prevent significant transboundary pollution, to take precautionary measures in the face of scientific uncertainty, to promote sustainable development, and so forth and so on. The International Court of Justice has weighed in on several of these norms, finding in its Nuclear Weapons advisory opinion that the obligation to respect the environment of other states is part of the "corpus of international law" (perhaps hedging its bets as to whether the obligation is custom or a general principle), and more recently, in the Pulp Mills case, that the principle of prevention is a customary rule.

Of course, like most ICJ pronouncements about customary international law, the ICJ's conclusion that the duty to prevent transboundary pollution is a rule of customary international law was made ex cathedra, with nary a citation to state practice or opinio juris. The ICJ's "methodology" in identifying custom is perhaps more extreme than most, but the ICJ is certainly not alone in failing to survey state practice and opinio juris when pronouncing about custom. The International Law Association (ILA), for example, cited only seven examples of state practice in support of its conclusion that the duty to inform is a norm of customary international law, out of the presumably countless instances in which states have undertaken activities with a significant risk of transboundary harm. Instead, the ILA's analysis emphasized the various resolutions and treaties in which the putative customary norm appeared. Indeed, even the "textbook" example (quite literally) of how to identify custom, the Paquete Habana case, cited the practice of fewer than ten countries in support of its conclusion that customary international law exempts fishing vessels from naval blockades during time of war.

I could go on and on. The examples all point to a disjunction between what Michael Reisman calls the "myth system" and the "operational code" of international law. The official story represents the myth system; what we actually observe is the operational code.

What would a more realistic account of custom look like? In my view, rather than constituting a single phenomenon, customary international law actually involves three interrelated but distinct phenomena:

- First, international courts and tribunals declaring the existence of extra-treaty norms- the standard of prompt, adequate and effective compensation in expropriation cases; the duty to prevent significant transboundary pollution; the principle of non-intervention.

- Second, states and other actors justifying their own behavior and criticizing the behavior of others on the basis of general rules.

- Third, the norms reflected in the actual behavior of states.

The first - the practice of international tribunals deciding cases-is best understood as a common law process. The second is what Hiram Chadosh has called "declarative law"- the discursive practice of states and expert bodies, who speak to one another in the language of norms. The third focuses on behavior rather than speech. All three are important: international common law if one faces litigation; declarative law in assessing the reputational costs of different courses of action; and behavioral norms in predicting what states will actually do. The three types of norms influence one another and sometimes yield the same result. But often they differ.

Given the deficiencies of traditional sources of theory, the question is, should we continue trying to elaborate the official story of customary international law as best we can (and, in the case of Michael Wood, that is a very well indeed)? Or should we admit that the emperor has no clothes, and try to come up with a theory that more accurately describes what is going on? Should we follow the example of Ptolemaic astronomers, who added epicycle upon epicycle to their descriptions of planetary motion, in their efforts to save the 
geocentric system? Or should we seek a paradigm shift, a new way of understanding the sources of international law?

To no one's surprise, I favor the last of these suggested solutions. What might such a paradigm shift look like? I tried to sketch out my general thinking in a piece entitled "Prologue to a Theory of Non-Treaty Norms," which appeared in Michael Reisman's festschrift, Looking to the Future, ${ }^{1}$ and from which the rest of this comment is drawn. An earlier article by Harlan Cohen entitled, "Rethinking the Doctrine of Sources" 2 proceeded along similar lines.

Rather than focus on the categories of treaties, custom, and general principles, I believe it is more useful to start by distinguishing between treaty and non-treaty law, since this is the basic dividing line in international law. Then, within the category of non-treaty law, we can classify norms along three dimensions: first, whether they are accepted directly or as a result of a secondary rule of recognition; second, whether they are the result of a conscious, purposive process, with identifiable authors, or arise in a more organic, diffuse way; and third, whether they reflect behavioral or discursive regularities.

Because of space limitations, I will focus in this comment only on the first dimension, which is based on H.L.A. Hart's distinction between norms that are accepted directly and norms that are accepted because they satisfy a "secondary" rule of recognition (or, to use the terminology of international law, a "formal source") that a community accepts as defining valid rules.

Depending on whether a primary norm is accepted directly or indirectly, the process for identifying rules is quite different. ${ }^{3}$ For primary rules that are accepted directly, the inquiry is a factual one: what non-treaty rules do states and other international actors, in fact, treat as guides to conduct? Do actors manifest acceptance of a putative norm as a standard of conduct? Does the norm guide their behavior? Do they justify their behavior in terms of the putative rule, and criticize others for violating it?

In contrast, for primary norms that are accepted because they conform to a secondary rule, the inquiry has both a factual and a legal component. First, we must identify the secondary rules — the formal sources-of the legal system. This requires determining what secondary rules are, in fact, accepted as defining valid rules. Having identified these formal sources, the task of identifying the primary rules then becomes a legal one, requiring us to determine which norms satisfy the accepted secondary rules.

For many normative systems, it is easy to determine whether rules are accepted directly or because they satisfy a secondary rule of recognition. Rules of fashion, etiquette, and word usage, for example, do not have a formal source. They are not accepted because they conform to an accepted norm-making process. Instead, they exist simply because a community of actors in fact treats them as guides to conduct. The same is true, I think, of customary law in traditional societies. In contrast, legislation in a constitutional democracy has a formal source - it is the product of an accepted secondary lawmaking process. That is why, with respect to statutes, we must always ask, is a statutory rule merely part of the law's myth system (because it was generated in accordance with the accepted legislative process) or is it, in fact, part of a community's operational code?

Treaties, like statutes, clearly fall into the second of Hart's two categories: states accept them as a formal source of law. By explicitly consenting to a treaty through signature, ratification or accession, a state consents to be bound. Whether non-treaty norms fall into Hart's first or second category, however, is less clear.

According to the official story, Article 38 of the ICJ Statute encapsulates the accepted secondary rules of recognition for international law, which include not only treaty-making, but also customary law and general

\footnotetext{
${ }^{1}$ Daniel Bodansky, Prologue to a Theory of Non-Treaty Norms, in LoOking to THE Future: Essays On InTERNATIONAL LAW IN HonOR OF W. Michael Reisman (Mahnoush Arsanjani et al. eds., 2010).

${ }^{2}$ Harlan Grant Cohen, Finding International Law: Retbinking the Doctrine of Sources, 93 IowA L. REv. 65 (2007).

3 See, e.g., Raphael M. Walden, Customary International Law: A Jurisprudential Analysis, 13 IsR. L. REv. 86, 91 (1978).
} 
principles. According to this approach, customary international law is not simply a description of the norms that actually guide the behavior of states; it is a formal source of law, like legislation or treaty-making. As a result, a norm can be a valid rule of customary law because it conforms to the secondary rule of recognition, even though many (perhaps even most) states do not accept it as a guide to their conduct.

Alternatively, non-treaty norms could rest on direct acceptance by states rather than on a secondary rule about customary law. When non-treaty rules emerge through a diffuse process of social interaction, acceptance may itself be an unconscious, non-deliberate process, not based on any secondary lawmaking rule. Just as it would be a mistake to ask-what is the secondary rule that creates a valid norm of fashion or etiquette? - it would be a mistake to analyze this kind of non-treaty law in terms of secondary rules.

Although conceptualizing custom as a factual description of the norms that actually regulate state behavior as opposed to a formal source of international law may seem like a distinction without a difference, the two accounts of custom differ in subtle ways. Consider, for example, the role of state practice. On the descriptive view of custom, regular state practice is evidence of a customary norm, and may be part of the causal story about the origin of a norm (because what is normal in a descriptive sense often becomes seen as normal in an evaluative sense). But, although the fact that other states generally accept a customary rule might cause a state to accept the rule, it does not provide a reason to accept the rule. In contrast, if consistent state practice is a formal source of custom, then it provides a legal reason for viewing a rule as a valid customary norm.

Which theory of non-treaty law is more descriptively accurate? To what degree are non-treaty norms accepted directly and to what degree are they created through an accepted lawmaking process? Can we ask only the factual question: Is a purported norm actually accepted by international actors? Or can we also ask the legal question: Is a norm a "valid" rule of international law under an accepted secondary rule?

In my view, the answer is not either-or. Non-treaty law is a heterogeneous phenomenon, which operates differently among different communities of actors - in some cases, through direct acceptance; in others, through a secondary lawmaking rule. The ICJ and ILA, in their findings of customary international law, assume a secondary lawmaking process involving precedent and the discursive practice of states and international institutions. But it is more questionable whether political decision-makers within states accept a secondary rule of non-treaty lawmaking, the products of which they recognize as law. I once heard the State Department's Legal Adviser observe that he never made an argument to the Secretary of State based on customary international law, because the argument would not carry any weight. And this was during a Democratic Administration that was, in theory, committed to the rule of international law!

Interestingly, the title of the ILC's second report-identification of customary international law-is agnostic about the two different theories of custom, since identifying custom could involve identifying the norms that states actually accept or the norms that conform to a secondary rule of customary law creation. In this respect, the change from the ILC's original title, "Formation and evidence of customary international law," is significant, since the original reference to "formation" seemed to suggest the secondary-rule theory of custom.

In any event, recognizing that customary law can be based on direct acceptance, not just on a secondary rule, helps solve one of the enduring paradoxes of customary law: namely, how states can act out of a sense of legal obligation in order to create a new customary norm, if the legal obligation does not exist until they have acted. The answer is that the early adopters of an emerging non-treaty norm accept the norm directly, not because of a (mistaken) belief that the norm is the product of a secondary lawmaking process. Subsequent adopters may accept the norm because they think it is a legal obligation, but the early adopters simply accept it as a legal obligation.

The ILC is a fundamentally conservative organization, so it should come as no surprise that its latest report on customary international law reflects the conventional view. Nor should it come as any surprise that the 
report is of a high professional standard. But, if the conventional view does not reflect how international actors, in fact, identify "custom," then technical excellence is not enough. We need a more realistic account of how international norms are recognized and applied. 